\title{
PEMBUATAN VCO MEMANFAATKAN BONGGOL NANAS SEBAGAI SUMBER BROMELIN DI DESA BALE KABUPATEN DONGGALA PROVINSI SULAWESI TENGAH
}

\author{
Jaya Hardi ${ }^{1}$, Syaiful Bahri ${ }^{1}$, Riza Aulia Putri Buheli ${ }^{1}$ \\ ${ }^{1}$ Universitas Tadulako, Palu, Indonesia \\ jr.hardi0803@gmail.com
}

\begin{abstract}
Abstrak: Desa Bale Kecamatan Tanatovea merupakan salah satu daerah tertinggal di Kabupaten Donggala, Provinsi Sulawesi Tengah. Mata pencaharian masyarakatnya adalah petani, khususnya petani kelapa. Hasil pertanian kelapa di Desa Bale hanya diolah dalam bentuk kopra dan lebih banyak dijual dalam bentuk bahan mentah sehingga penghasilan yang mereka dapatkan kurang maksimal. Permasalahan tersebut dapat diatasi dengan membuat olahan kelapa lainnya melalui teknologi murah, sederhana dan dapat dipasarkan langsung dengan nilai jual yang tinggi. Produk olahan kelapa yang dapat dikembangkan untuk meningkatkan pendapatan masyarakat setempat diantaranya adalah Virgin Coconut Oil (VCO). Tujuan dari kegiatan program pengabdian ini adalah untuk memberikan pengetahuan dan keterampilan kepada masyarakat dalam memanfaatkan krim santan kelapa menjadi VCO dengan menggunakan enzim bromelin dari bonggol nanas. Tahapan awal program pengabdian adalah memberikan penyuluhan kepada masyarakat, memberikan pelatihan pembuatan krim santan, pembuatan sari dan bubur bonggol nanas, dan diakhiri dengan pembuatan VCO. Hasil program pengabdian ini adalah mitra pengabdian dapat memahami teknologi dan mengaplikasikannya dalam pembuatan VCO dengan memanfaatkan limbah bonggol nanas. Pada program pengabdian ini, produk VCO yang dihasilkan dengan menggunakan sari bonggol nanas lebih banyak dibandingkan dengan bubur bonggol nanas. Hasil pelaksanaan panyuluhan dan pelatihan menunjukkan tingkat kepuasan peserta sebesar lebih dari $97 \%$. Pembuatan VCO dengan memanfaatkan bonggol nanas menjadi alternatif industri skala kecil untuk masyarakat.
\end{abstract}

Kata Kunci: bonggol nanas, desa Bale, kelapa, Virgin Coconut Oil (VCO)

\begin{abstract}
Bale Village, Tanatovea Subdistrict, is one of the underdeveloped areas in Donggala Regency, Central Sulawesi Province. The people are farmers, especially coconut farmers. Coconut agricultural products in Bale village are only processed in the form of copra and are mostly sold in the form of raw materials with less income. This problem can be solved by making other coconut products through cheap and simple technology that can be marketed directly with a high selling value. The coconut processed products can be developed to increase local people's income, including Virgin Coconut Oil (VCO). The purpose of this community service activity is to provide knowledge and skills to the farmers in using coconut cream to be processed as VCO by using the enzyme bromelain from pineapple cobs waste. The initial stage of the activity was to provide counseling to the community, then conduct a short training to produce coconut cream, extract and pulp of pineapple humps, and finally produce VCO. The results show that the participants can understand the technology provided and apply it to produce VCO using pineapple extracts waste. In this program, the VCO produced using the pineapple extract is more than that of the pineapple pulp. The results of the program reveal that the participants' satisfaction level is over $97 \%$. Producing VCO using pineapple humps is an alternative for a small-scale industry for the community.
\end{abstract}

Keywords: pineapple cobs waste, Bale village, coconut, Virgin Coconut Oil (VCO)

\section{Pendahuluan}

Indonesia merupakan negara tropis sehingga memiliki potensi besar dalam produksi kelapa. Sulawesi Tengah sebagai salah satu provinsi di Indonesia, memiliki beberapa daerah dengan tingkat produksi kelapa yang tinggi, salah satunya adalah Kabupaten Donggala. 
Penduduk dibeberapa kecamatan dan desa di Kabupaten Donggala memiliki mata pencaharian sebagai petani kelapa, salah satunya adalah Desa Bale yang terletak di Kecamatan Tanantovea. Masyarakat di Kecamatan Tanantovea umumnya memiliki pekerjaan berkebun dengan hasil perkebunan terbeasr adalah perkebunan kelapa. Pada tahun 2016, jumlah produksi kelapa mencapai 704 ton (Badan Pusat Statistik Kabupaten Donggala, 2020). Desa Bale memiliki perkebunan kelapa yang cukup luas dan menjadi salah satu penghasil kelapa di Kab. Donggala. Namun demikian, pengolahan kelapa masih sangat terbatas pada pembuatan kopra, sedangkan harga kopra seringkali mengalami fluktuasi. Oleh karena itu, masyarakat di Desa Bale memerlukan pembinaan untuk mengolah kelapa menjadi beberapa jenis produk olahan. Salah satu produk olahan kelapa yang dapat menjadi solusi untuk mengatasi masalah di Desa Bale adalah dengan melakukan produksi Virgin Coconut Oil (VCO).

VCO merupakan hasil olahan buah kelapa berupa modifikasi minyak dengan kadar air dan kadar asam lemak bebas yang rendah, berwarna bening, berbau harum, mempunyai daya simpan lebih dari 12 bulan, serta memiliki nilai jual tinggi karena memiliki banyak manfaat untuk kesehatan (Rahmawati \& Khaerunnisya, 2018). Produk VCO mengandung sekitar 64\% asam lemak jenuh rantai sedang yang terdiri lebih dari 50\% asam laurat (C12), 6-7\% asam kaprat (C10), dan 8\% asam kaprilat (C8) (Sulistio, Rahayu, \& Poeloengan, 2009). VCO dapat diproduksi dari minyak kelapa melalui proses fermentasi dan enzimatis (Putri, Wijiastuti, \& Setijanti, 2020; Sinaga, Simbolon, \& Setyaningrumm, 2018). Enzim yang dapat dimanfaatkan untuk memperoleh VCO adalah enzim bromelin yang sangat mudah diekstraksi dari limbah bonggol nanas (Sari, Herdiana, \& Amelia, 2010). Penelitian pembuatan VCO menggunakan enzim bromelin telah banyak dilakukan. Edahwati (2011) melaporkan bahwa konsentrasi daging buah nanas sebesar 8 gram menghasilkan VCO optimum sebanyak 20,43\%. Penelitian Palilingan \& Pungus (2018) menjelaskan bahwa konsentrasi ekstrak batang buah nanas yang optimum menghasilkan rendemen tertinggi pada konsentrasi $20 \%$ sebesar $35.90 \%$ daripada rendemen VCO kontrol 31.96\%.

Kurangnya pengetahuan dari masyarakat di Desa Bale mengenai pemanfaatan bonggol nanas sebagai sumber enzim untuk pembuatan VCO menjadi perhatian utama dengan tujuan meningkatkan keterampilan masyarakat setempat dalam pengembangan hasil olahan kelapa. Oleh karena itu, salah satu usaha yang dapat membantu peningkatan keterampilan petani kelapa Desa bale adalah dengan melakukan pendampingan penerapan teknologi tepat guna yang mudah dan murah berupa pembuatan VCO. Hasil dari pendampingan ini selanjutnya dapat menjadi peluang usaha baru bagi petani kelapa di Desa Bale, Kecamatan Tanantovea.

\section{Metode}

Pengabdian dilakukan dengan menggunakan metode edukatif yang meliputi penyuluhan kepada peserta pengabdian atau masyarakat mengenai manfaat dari bonggol nanas sebagai sumber enzim bromelin dan pemanfaatannya pada pembuatan VCO dengan menggunakan metode yang sederhana, serta pelatihan singkat mengenai cara produksi VCO menggunakan sari bonggol nanas dan bubur bonggol nanas sebagai sumber enzim bromelin. Pengabdian 
dilakukan pada bulan Juli 2020 di Dusun V, Desa Bale Kecamatan Tanantovea Kabupaten Donggala Provinsi Sulawesi Tengah. Peserta pengabdian melibatkan kelompok petani kelapa Dusun V Desa Bale.

Tahapan pengabdian yang dilakukan meliputi, penyiapan alat dan bahan, transfer teknologi, pendampingan, dan evaluasi hasil pengabdian.

a. Persiapan alat dan bahan

Persiapan alat dan bahan dilakukan setelah koordinasi dengan seluruh tim pengabdian. Bahan utama yang dipersiapkan ialah kelapa parut tua, nanas mengkal, dan air. Alat yang dipergunakan, meliputi saringan santan, blender, baskom, pisau, parutan, kain saring, dan wadah inkubasi.

b. Transfer teknologi

Transfer teknologi meliputi penyuluhan dan pelatihan. Penyuluhan dilakukan diawal untuk memberikan pengetahuan awal bagi peserta pengabdian yang dilanjutkan dengan pelatihan singkat. Tahapan pelatihan meliputi pembuatan krim santan kelapa, pembuatan sari dan bubur bonggol nanas, dan diakhiri dengan pembuatan VCO. Tahapan awal yang dilakukan adalah membuat krim santan dengan tahapan: Buah kelapa setengah tua diambil dagingnya, kemudian diparut dan ditambahkan air dengan perbandingan 1:1 (b/v). Campuran kelapa dengan air ini diremas-remas selama 15-20 menit. Setelah itu disaring dengan menggunakan saringan kelapa dan dibiarkan 2 jam didalam gelas kimia 2 L. Setelah terbentuk dua lapisan, diambil bagian atas yang kemudian digunakan pada pembuatan VCO (Dewi \& Rahmawati, 2012).

Sari bonggol nanas diperoleh dengan menghancurkan bonggol nanas yang telah dipisahkan dari buahnya menggunakan blender (Sinaga et al., 2018). Bonggol yang telah hancur selanjutnya disaring menggunakan kain saring dan diperoleh sari bonggol nanas. Sementara itu, bubur bonggol nanas diperoleh dengan cara mamarut bonggol nanas. Pembuatan VCO dilakukan dengan mencampurkan sari bonggol nanas dan krim santan dengan perbandingan $1: 2(\mathrm{v} / \mathrm{v})$, atau bubur bonggol nanas perbandingan terhadap krim santan 1:2 (b/v). Campuran didiamkan selama 48 jam dan minyak yang terdapat pada bagian atas wadah selanjutnya dipisahkan. Minyak yang diperoleh merupakan minyak kelapa murni atau VCO (modifikasi metode Sari et al., 2010). Metode pembuatan VCO diuraikan lebih sederhana dalam bentuk diagram kerja pada Gambar 1.

c. Pendampingan

Pendampingan berupa diskusi dengan peserta pengabdian setelah proses pelatihan selesai. Diskusi meliputi kendala alat dan bahan serta metode yang mungkin dapat dijumpai pada pembuatan VCO baik saat pelatihan ataupun pada saat pengaplikasiannya dalam bentuk usaha kecil atau industri rumahan.

d. Evaluasi pengabdian

Tahapan akhir dari pengabdian yang dilakukan ialah evaluasi hasil pengabdian. Tahapan ini dilakukan dengan menyebarkan kuisioner kepuasan kepada peserta pengabdian mengenai proses jalannya kegiatan pengabdian, pelayanan tim pengabdi, dan jawaban dari tim pengabdi terhadap pertanyaan dari peserta. 


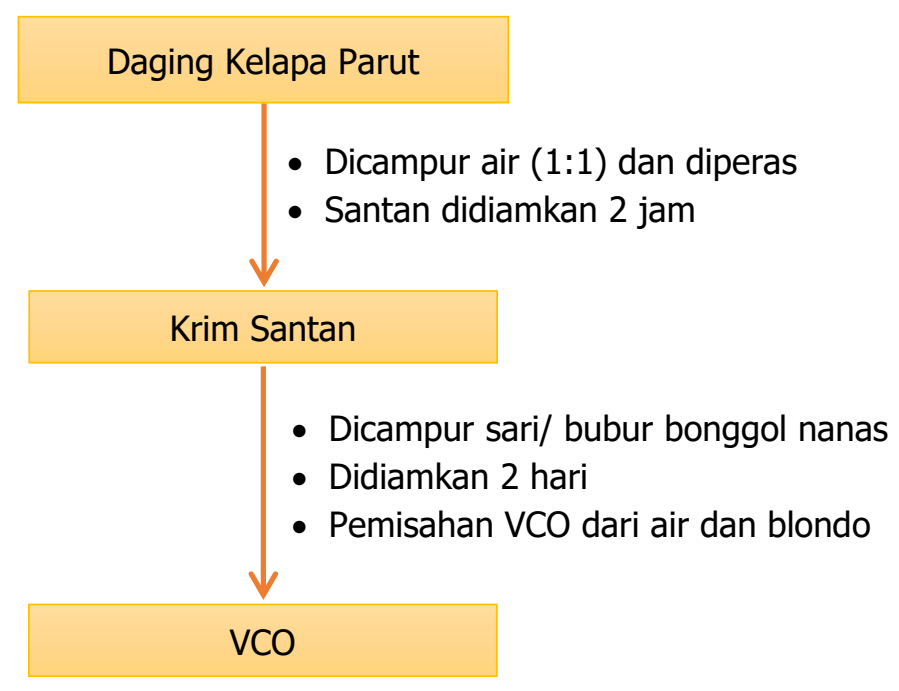

Gambar 1. Proses pembuatan VCO

\section{Hasil dan Pembahasan}

Masyarakat di Desa Bale Kecamatan Tanantovea pada umumnya mengolah kelapa dalam bentuk kopra sehingga kurang mampu meningkatkan nilai guna kelapa. Pengenalan pembuatan VCO dengan memanfaatkan limbah nanas menjadi salah satu solusi sederhana dan murah dalam mengatasi masyarakat tersebut. Peserta pengabdian yang terlibat pada kegiatan yang dilakukan berjumlah 35 orang. Kegiatan pelatihan dan penyuluhan dilakukan secara singkat dikarenakan dalam masa pandemik, sehingga tidak dapat dilakukan kerja secara berkelompok atau kegiatan pengabdian dilakukan sesuai dengan protokol kesehatan. Hasil penyuluhan yang dilakukan, menunjukkan bahwa masyarakat sangat antusias untuk mendapatkan pelatihan pembuatan VCO dari Tim Pengabdi yang ditunjukkan dengan banyaknya pertanyaan dari peserta (Gambar 2).

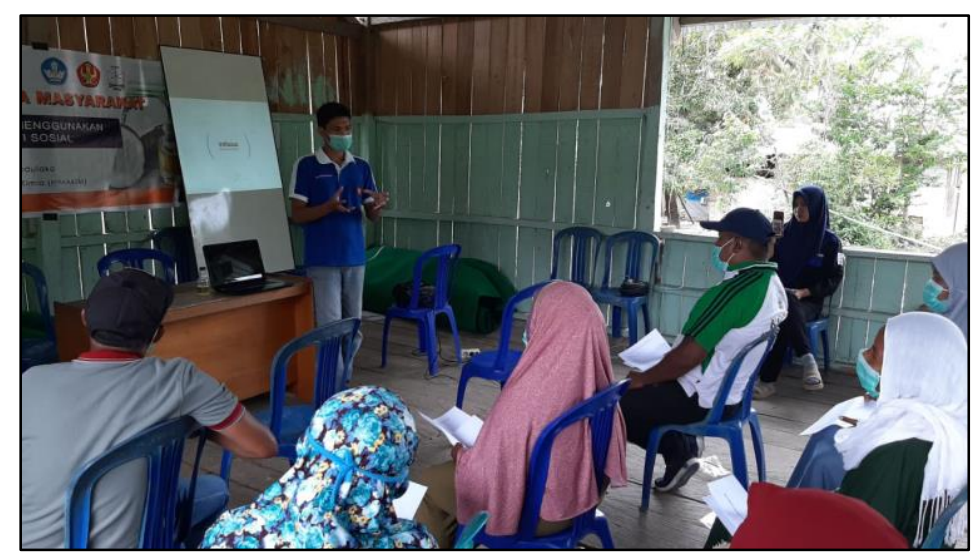

Gambar 2. Penyuluhan pembuatan VCO

Penggunaan bonggol nanas menjadi hal baru bagi masyarakat mitra, karena yang mereka ketahui selama ini hanyalah proses pembuatan VCO dengan menggunakan metode pengasaman dan pancingan. Pemilihan bonggol nanas dikarenakan di dalam bonggol memiliki 
bromelin yang tinggi (Santi, Restuhadi, \& Ibrahim,, 2017). Masri (2013) melaporkan bahwa dalam bonggol nanas mampu menghasilkan bromelin dengan kadar protein 37,2 mg/ml dan aktivitas proteolitik mencapai 1,08 U/gram. Tahapan pelatihan singkat yang diberikan, yaitu pembuatan krim santan sebagai langkah awal. Ampas kelapa yang telah dicampurkan dengan air (perbandingan 1:1) berhasil mendapatkan dua lapisan setelah didiamkan selama dua jam. Lapisan atas merupakan krim santan dan bagian bawah ialah santan sisa dan air (Gambar 3). Langkah kedua berupa pembuatan sari bonggol nanas dengan menggunakan blender. Bonggol nanas diblender dengan penambahan air secukupnya, sedangkan bubur bonggol nanas cukup dengan proses pemarutan (Gambar 4). Kedua hal ini dilakukan untuk menunjukkan kepada masyarakat tentang potensi dari kedua bentuk bahan, tetapi dengan metode yang sangat sederhana. Sari bonggol nanas memungkinkan enzim bromelin lebih mudah untuk berinteraksi dengan substrat krim santan dibandingkan dengan bubur bonggol nanas karena bromelin telah terekstrak oleh air. Pada tahapannya, masyarakat dijelaskan tentang kandungan bromelin sebagai enzim proteolitik pada bonggol nanas, berfungsi untuk memecah protein santan hingga terkoagulasi dan akhirnya minyak dapat terpisahkan dari protein santan.

Tahapan akhir dari pelatihan ialah pembuatan VCO dengan menggunakan enzim bromelin dari bonggol nanas. Pada tahapan ini, diperkenalkan kepada mitra tentang cara inkubasi krim santan bersama dengan sari atau bubur bonggol nenas selama 24 jam. Toples plastik digunakan sebagai wadah inkubasi atau reaktor produksi VCO. Hasil penyimpanan selama dua hari diperoleh tiga lapisan, yaitu lapisan minyak, lapisan blondo dan lapisan air pada bagian bawah. Perbedaan hasil dari penggunaan sari dan bubur bonggol nanas sangat terlihat jelas. Hasil VCO dengan penggunaan sari bonggol nanas menunjukkan pemisahan yang sangat jelas dan volume yang jauh lebih banyak dibandingkan dengan penggunaan bubur bonggol nanas (Gambar 5). Hasil ini menjadi pengetahuan baru bagi masyarakat mitra, bahwa sari bonggol nanas jauh lebih baik untuk mendapatkan VCO dibandingkan bubur bonggol nanas.

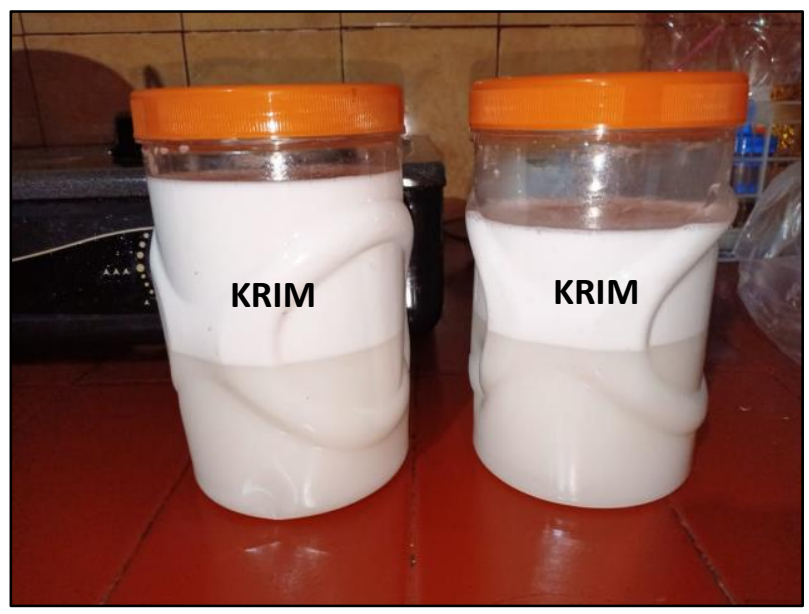

Gambar 3. Tahapan pembuatan krim santan 

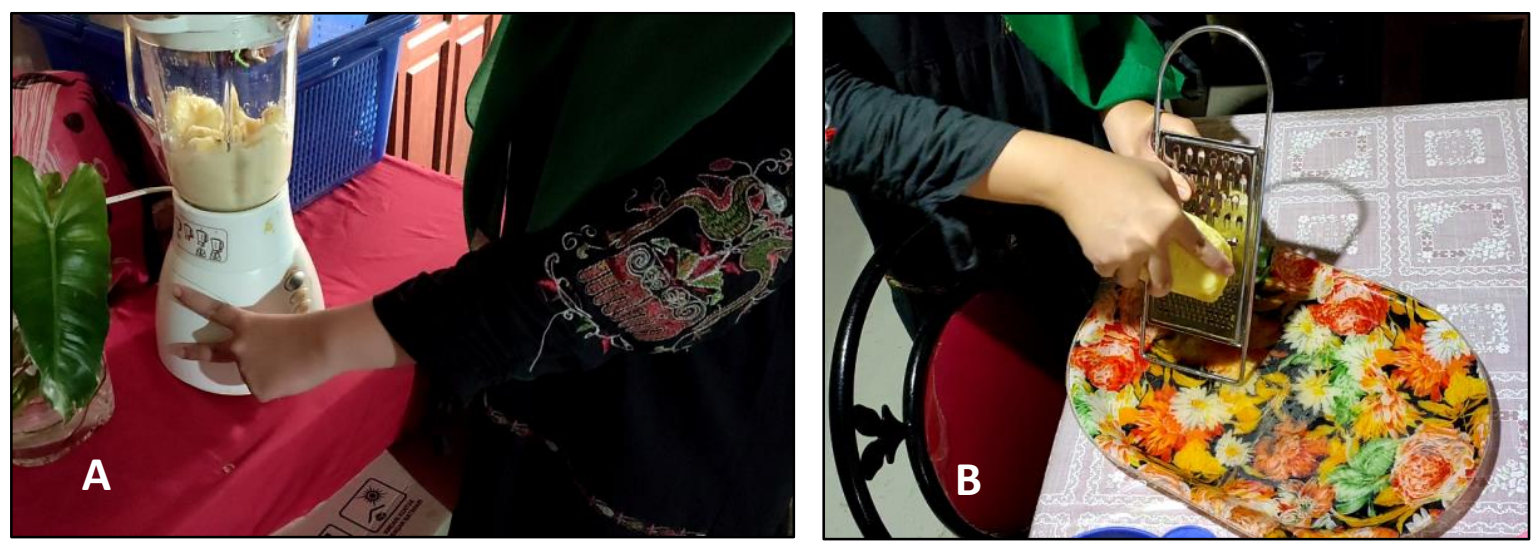

Gambar 4. Tahapan preparasi (A) sari bonggol nanas dan (B) bubur bonggol nanas

Effendi, Pratjojo, \& Sumarni (2012) telah membuktikan sebelumnya bahwa sari bonggol nanas mampu menghasilkan VCO. Pada penelitian tersebut, perbandingan volume santan dan sari bonggol nanas 8:6 mampu menghasilkan minyak sebanyak $97 \mathrm{~mL}$ atau rendemen $12 \%$. Hasil penelitian tersebut menjadi dasar dalam pemanfaatan sari bonggol nanas sebagai sumber enzim bromelin pada pembuatan VCO.

Hasil dari seluruh pelatihan yang dilakukan, diperoleh bahwa metode pembuatan VCO yang diperkenal dapat diterima dengan baik oleh masyarakat setempat/peserta pelatihan. Tahapan terakhir dari pengabdian ialah pendampingan kelompok petani. Pendampingan dilakukan dengan tujuan untuk melihat seberapa paham masyarakat terhadap VCO yang dibuat. Melalui proses pendampingan dilakukan proses diskusi untuk mengetahui faktor apa saja yang menjadi kendala dalam pembuatan VCO. Antusiasme warga dalam menerapkan teknologi yang diperkenalkan cukup tinggi. Hal tersebut dapat dilihat pada hasil survey kepuasan yang dilakukan pada saat pelaksanaan pengabdian (Gambar 6).

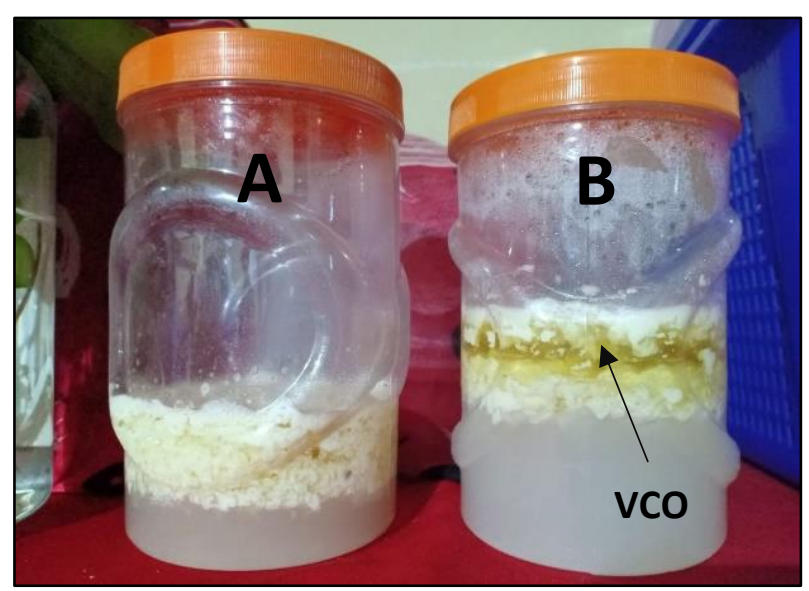

Gambar 5. Tampilan pemisahan VCO setelah dua hari masa inkubasi menggunakan (A) bubur bonggol nanas dan (B) sari bonggol nanas 


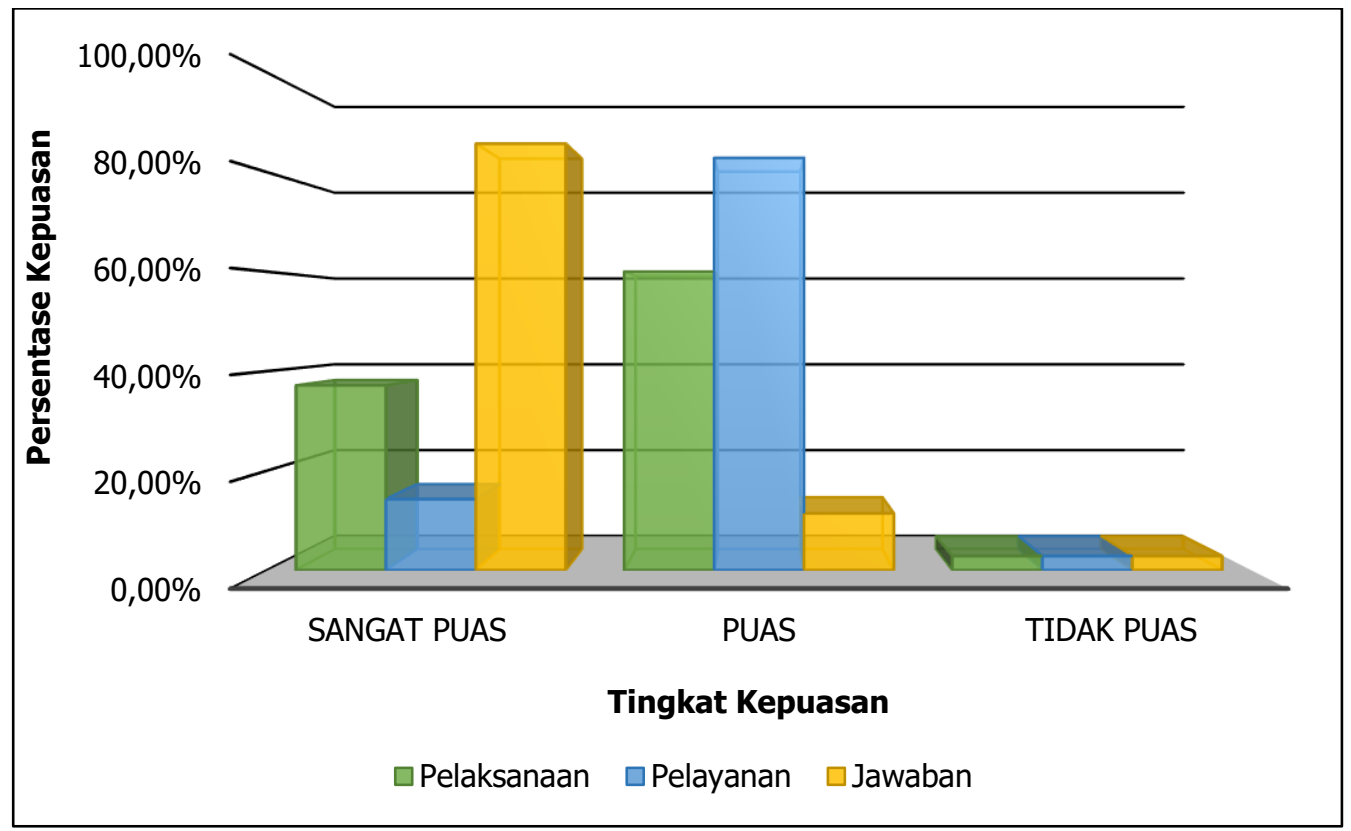

Gambar 6. Grafik tingkat kepuasan dari peserta pengabdian

Tingkat kepuasan dari peserta pada pelaksanaan secara menyeluruh, pelayanan tim pengabdi, dan jawaban tim pengabdi atas pertanyaan peserta berada persentase lebih dari $97 \%$ atau 34 orang dengat skala kepuasan "puas" hingga "sangat puas" (Tabel 1). Kepuasan peserta terhadap rangkaian pelaksanaan pengabdian dominan pada tingkat puas, yaitu 60\%. Kepuasan terhadap pelayanan pengabdi selama pelaksanaan pengabdian juga dominan pada tingkat puas, yaitu $82,86 \%$. Sementara itu, kepuasan peserta terhadap jawaban pengabdian atas pertanyaan yang diajukan dominan pada tingkat sangat puas, yaitu $85,71 \%$. Harianingsih dan Kusumahningsrum (2018) juga melaporkan hasil pengabdian pembuatan VCO di desa Patemon Gunung Pati Semarang bahwa pembuatan VCO sangat mudah untuk dipahami oleh peserta dengan persentase $80 \%$. Hal tersebut menunjukkan bahwa pengabdian pengolahan kelapa menjadi VCO adalah bentuk penerapan teknologi yang sederhana dan sangat mudah dipahami oleh peserta pengabdian. Berdasarkan data tersebut, maka hasil dari pengabdian yang dilakukan sangat memungkinkan untuk dikembangkan oleh masyarakat setempat dalam produksi VCO pada skala rumahan.

Tabel 1. Hasil survey kepuasan peserta pengabdian

\begin{tabular}{clccc}
\hline No. & \multicolumn{1}{c}{ Indikator Kepuasan } & $\begin{array}{c}\text { Sangat } \\
\text { Puas }\end{array}$ & Puas & $\begin{array}{c}\text { Tidak } \\
\text { Puas }\end{array}$ \\
\hline 1 & Kepuasan dengan kegiatan pengabdian masyarakat & 13 & 21 & 1 \\
2 & $\begin{array}{l}\text { Kepuasan dengan pelayanan Tim Pengabdi } \\
\text { Kepuasan dengan jawaban dan penjelasan Tim Pengabdi } \\
\text { terhadap pertanyaan peserta }\end{array}$ & 5 & 29 & 1 \\
\hline
\end{tabular}


Program pengabdian ini diharapkan akan berlanjut pada proses pemurnian VCO menggunakan adsorben hingga pada proses pengemasan produk VCO untuk keperluan pemasaran. Keberlanjutan tersebut direncanakan pada periode pengabdian berikutnya. Melalui tahapan-tahapan tersebut, diharapkan masyarakat di Dusun V Desa Bale dapat memiliki industri rumahan baru demi meningkatkan pendapatan masysrakat setempat khususnya bagi para petani kelapa.

\section{Kesimpulan}

Hasil pelaksanaan kegiatan pengabdian dapat diambil kesimpulan bahwa Kelompok Mitra memberikan respon yang sangat positif terhadap kegiatan ini dan masyarakat mitra antusisasi untuk dapat memproduksi produk VCO sebagai salah satu produk bisnis di Dusun V Desa Bale yang dibuktikan dengan tingkat kepuasaan terhadap pelaksanaan kegiatan pengabdian, yaitu taraf "tidak puas" 2,86\%, "puas" 60\%, dan "sangat puas" 37,14\% atau total taraf "puas" hingga "sangat puas" lebih dari 97\%. Hasil pengabdian juga menerangkan bahwa penggunaan sari bonggol nanas dipilih menjadi sumber enzim bromelain yang paling baik dibandingkan bubur bonggol nanas karena menghasilkan volume VCO yang lebih banyak. Produk VCO yang dihasilkan perlu dianalisis mutu di laboratorium sehingga masyarakat akan lebih yakin dalam mengembangkan produksi VCO baik pada indusrti menengah maupun industri rumahan.

\section{Ucapan Terima Kasih}

Ucapan terimakasih disampaikan kepada Rektor Universitas Tadulako dan Pimpinan Fakultas MIPA Universitas Tadulako yang telah memberikan hibah pengabdian kepada masyarakat Tahun 2020 yang tercantum pada Surat Keputusan Rektor Universitas Tadulako Nomor 4008/UN28/KP2020, sehingga pengabdian dapat diselesaikan dengan baik.

\section{Referensi}

Badan Pusat Statistik Kabupaten Donggala. (2020). Kecamatan Tanantovea dalam Angka 2020. BPS Kabupaten Donggala.

Dewi, S., \& Rahmawati, S. (2012). Pemanfaatan protease dari akar agave, daun palado (agave), dan daun nanas pada proses pembuatan virgin coconut oil (VCO). Jurnal Matematika dan Sains, $8(2), 231-238$.

Edahwati, L. (2011). Aplikasi Penggunaan Enzym Papain dan Bromelin Terhadap Perolehan VCO. UPN Press.

Effendi, A. M., Pratjojo, W., \& Sumarni, W. (2012). Optimalisasi penggunaan enzim bromelin dari sari bonggol nanas dalam pembuatan minyak kelapa. Indonesian Journal of Chemical Science, 1(1), 1-6. Diakses di: https://journal.unnes.ac.id/sju/index.php/ijcs/article/view/573/10098

Harianingsih \& Kusumahningsrum, M. (2018). Pelatihan Pembuatan Virgin Coconut OiL (VCO) di Patemon Gunungpati Semarang. Abdimas Unwahas, 3(1), 36-39.

Masri, M. (2013). Isolasi dan pengukuran aktivitas enzim bromelin dari ekstrak kasar bonggol nanas (ananas comosus) pada variasi suhu dan PH. BIOSEL (Biology Science and Education): Jurnal Penelitian Science Dan Pendidikan, 2(1), 70-79. https://doi.org/10.33477/bs.v2i1.149

Palilingan, S. C., \& Pungus, M. (2018). Produksi enzimatis Virgin Coconut Oil (VCO) dengan enzim bromelin serta pemurniannya menggunakan adsorben zeolit. Fullerene Journal of Chemistry, 3(2), 70-74. https://doi.org/10.37033/fjc.v3i2.41 
Putri, E. S. Y., Wijiastuti, W., \& Setijanti, H. B. (2020). Pembuatan Virgin Coconut Oil (VCO) Menggunakan Enzim Bromelin di Kampung Kekupu, Depok. JAST: Jurnal Aplikasi Sains Dan Teknologi, 4(1), 38-43. https://doi.org/10.33366/jast.v4i1.1557

Rahmawati, E., \& Khaerunnisya, N. (2018). Pembuatan VCO (Virgin Coconut Oil) dengan proses fermentasi dan enzimatis. Journal of Food and Culinary, 1, 1-6. https://doi.org/10.12928/jfc.v1i1.1575

Santi, F., Restuhadi, F., \& Ibrahim, A. (2017). Potensi ekstrak kasar enzim bromelin pada bonggol nanas (ananas comosus) sebagai koagulan alami lateks (hevea brasiliensis). Jurnal Online Mahasiswa Fakultas Pertanian Universitas Riau, 4(1), 1-13.

Sari, T., Herdiana, E., \& Amelia, T. (2010). Pembuatan VCO dengan metode enzimatis, dan koversinya menjadi sabun padat transparan. Jurnal Teknik Kimia, 17(3), 50-58.

Sinaga, E. H., Simbolon, A. F., \& Setyaningrumm, B. (2018). Pembuatan Virgin Coconut Oil (VCO) dari Kelapa Hibrida dengan metode enzimatis dan aplikasinya sabun padat transparan. Jurnal Chemurgy, 1(1), 16. https://doi.org/10.30872/cmg.v1i1.1134

Sulistio, J., Rahayu, R., \& Poeloengan, M. (2009). Ekstraksi secara enzimatik minyak kelapa murni (VCO) dan uji pra-klinis menggunakan mencit DDY. Berk. Penel. Hayati Edisi Khusus, 3A, 101106. 